\title{
The Vowel System of Jewish Bukharan Tajik: With Special Reference to the Tajik Vowel Chain Shift
}

\author{
Shinji Ido* \\ Graduate School of Humanities, Nagoya University, Nagoya, Japan \\ ido@nagoya-u.jp
}

\begin{abstract}
The present article describes the vowel chain shift that occurred in the variety of Tajik spoken by Jewish residents in Bukhara. It identifies the chain shift as constituting of an intermediate stage of the Northern Tajik chain shift and accordingly tentatively concludes that in the Northern Tajik chain shift Early New Persian $\bar{a}$ shifted before $\bar{o}$ did, shedding light on the process whereby the present-day Tajik vowel system was established. The article is divided into three parts. The first provides an explanation of the variety of Tajik spoken by Jewish inhabitants of Bukhara. The second section explains the relationship between this particular variety and other varieties that have been used by Jews in Central Asia. The third section deals specifically with the vowel system of the variety and the changes that it has undergone since the late 19th century.
\end{abstract}

\section{Keywords}

Tajik - New Persian - vowel system - Judeo-Iranian - Bukharan Tajik - Bukharan Jews

\section{Introduction}

This article is concerned with the vowel system of the variety of Tajik spoken by the Jewish residents in Bukhara. It compares the vowel system of this particular variety with that of the same variety reconstructed based on a centuryold text. The comparison shows that the variety likely underwent a vowel chain

\footnotetext{
* The author acknowledges financial support for this research from the Japan Society for the
} Promotion of Science (Grant-in-Aid for Scientific Research, C \#2537049o). 
shift in which $/ \mathrm{o} /$ and $/ \mathrm{o} /$ became $/ \mathrm{\theta} /$ and $/ \mathrm{o} /$, respectively. The present article identifies this chain shift as constituting part of the Northern Tajik vowel shift. Following the introduction, this article is organized in three sections. The first section provides an explanation of the variety of Tajik spoken by the Jewish inhabitants of Bukhara. The second explains the relationship between this variety and other varieties that have been used by Jews in Central Asia. The third section traces the changes that have taken place in the vowel system of the variety in question.

\section{The Language of Jews in Bukhara}

The language variety whose vowel system is described in this article is Bukharan Tajik as spoken by the Jewish inhabitants of Bukhara. ${ }^{1}$ This article refers to this variety as Jews' Bukharan Tajik (hereafter abbreviated as JBT), offering no stance on its linguistic distinctiveness from Bukharan Tajik or its uniformity with other (Tajik) varieties spoken by Jews in Central Asian towns other than Bukhara (such as Samarkand, Kokand, Dushanbe, and Tashkent). Accordingly, in this article, the term 'Bukharan Tajik,' when used in contrast with JBT, is to be understood as referring to 'Bukharan Tajik as spoken by non-Jewish inhabitants of Bukhara,' or 'Bukharan Tajik in general.' Also, no assumption is made in the present article that JBT is sufficiently autonomous to be regarded a separate language from Bukharan Tajik. ${ }^{2}$ Not only are JвT and Bukharan Tajik mutually fully intelligible, but residents of Bukhara do not appear to regard J В $\mathrm{T}$ as distinct from Bukharan Tajik; nor do Jewish residents of Bukhara appear to be perceived by their fellow townsmen, namely Bukharan Tajik speakers, as having a discernible accent, let alone a distinct dialect or language. ${ }^{3}$ Apparently the perception that J вт does not differ from Bukharan Tajik is shared by my Jewish consultants, all of whom declared the main language they use with their parents to be /tod,iki/ 'Tajik,' which, in the context of

1 For a concise description of Bukharan Tajik and a note on its mutual (un)intelligibility with the standard Tajik of Tajikistan and Iranian Persian, see Ido 2012:13-14; 2014.

2 In fact, whether Jвт has ever been sufficiently unique to be regarded a separate language from Bukharan Tajik is open to debate. This situation is comparable to that of Crimean Karaim, whose autonomy from Crimean Tatar has been an issue of contention (see, e.g., Jankowski 2003:109-112).

3 See, for instance, the transcript of an interview with a Bukharan university lecturer (Ido 2007:86), where the interviewee dismisses the idea that Jew's Bukharan Tajik may be different from his Bukharan Tajik. 
our interviews, ${ }^{4}$ referred more or less specifically to Bukharan Tajik. ${ }^{5}$ Clearly, at the time of fieldwork (August 2013), linguistic discrepancies, if any, between JBT and Bukharan Tajik were either negligible or indiscernible for the average Bukharan Tajik speaker, as they were for my Jewish consultants in Bukhara. ${ }^{6}$

To be sure, a distinction between JBT and Bukharan Tajik has historical relevance, at least in written language. Pre-Soviet texts written by Jews from Bukhara $^{7}$ exhibit some peculiarities, if primarily in the lexicon and/or script,

4 During fieldwork, the majority of the questions directed towards the consultants were asked (in Bukharan Tajik, in which /todziki/ primarily refers to Bukharan Tajik) by an assistant who is a non-Jewish native speaker of Bukharan Tajik. The present author would intervene in interviews speaking both Bukharan Tajik and Uzbek.

5 Indeed, one of the consultants, after stating that the language he uses at home was /todiki/, paraphrased it as /buxoroja tockikec/ '(the) Tajik (language) of Bukhara.'

6 Invoking Benor's (2008:1068) theoretical construct of 'the distinctively Jewish linguistic repertoire,' the Jewish residents in Bukhara may be seen as not having a large distinctively Jewish linguistic repertoire at their disposal. There may exist linguistic features or combinations thereof which, while not manifest at the level of consciousness, distinguish the speech of Jews in Bukhara from that of the non-Jewish inhabitants. However, even if they do, it would prove difficult to demonstrate with any certainty that such linguistic features are unique to the speech or writings of Jews in Bukhara, because Bukharan Tajik is not a standardized variety and accordingly allows for a wide range of idiosyncrasy in pronunciation and grammar among its speakers. For instance, one of my consultants used / zubon/ for 'language,' for which, incidentally, Hakham (1902/3: 'language,' while my non-Jewish Bukharan assistant used /zabon/. However, both /zabon/ and /zubon/ exist in Bukharan Tajik in general and, accordingly, /zubon/ cannot be associated exclusively with the speech of the Jews of Bukhara. Another consultant used /oilo/ for 'family', for which most of the Bukharans I know use /oila/, but determining whether /oilo/ is uniquely JBT would be difficult for the same reason. Incidentally, a dictionary compiled by a Jew from Bukhara has ъоила "oila 'family' as an entry (Gulkarov 1998:240). According to the compiler (Gulkarov 1998:19), the phoneme transcribed with «ъ〉 is the voiced pharyngeal 'plosive' (взрьвной звук), by which he probably means either the voiced pharyngeal fricative [ $\mathrm{Y}]$ or the voiceless glottal plosive [?]. The glottal plosive is present in the consultant's pronunciation of /oilo/, but here again no exclusive association between the sound and Jвт can be established, because the glottal plosive preceding the word-initial vowel is a feature of Bukharan Tajik in general (see Ido 2014:90).

7 They include Dāniyal-nāma written in 1606 by Khwāja Bukhārā'î, a 17th-century Jewish author who was apparently from Bukhara (Shapira 2010a:25; 2010b:161), works of Yūsuf Yahūdī (Bacher 1899), who was also apparently from Bukhara (see Moreen 2000:147, 269), and works of Simon Ḥakham (see the third section). Khwāja Bukhārāî is variously referred to as Khwājah Bukhāraī (Margoliouth 1894:119), Khwaje of Bukhara (Shterenshis 2002:84), Khāja Bukhārāī (Lazard et al. 2007:555). There also exist other pre-Soviet texts written by Bukharan Jews, such as Khudāidād (Salemann 1897; Bacher 1898; Moreen 2000:238-242; 
that set them apart from other texts originating from Bukhara. For example, a literary prose work written by Simon Hakham, a Jew from Bukhara, is sprinkled with Hebrew words, e.g., לשון הקודש 'holy tongue' (Hakham 1902/3: unpaginated preface), and in this respect contrasts with texts written by Hakham's non-Jewish contemporaries. Jв т may also have served as a basis for the semistandardized 'language of local Jews' (see the explanation of ZJM in the following section), which was apparently devised so as to be distinct from the Tajik of non-Jewish Tajik speakers. ${ }^{8}$ Hence, in the view of those who were involved in the standardization, Jв т could be identified as distinct from the Bukharan Tajik of non-Jews. ${ }^{9}$ Clearly, however, these facts do not entail the linguistic autonomy of JвT as a spoken variety from Bukharan Tajik. In addition, even if we assume the existence of linguistic features or particular combinations thereof which, while not manifest at the level of consciousness, distinguish the speech of Jews in Bukhara from that of non-Jewish inhabitants, JBT can still be unproblematically identified as belonging to Northern Tajik dialects, of which Bukharan Tajik is one.

Birnbaum 2011a), the authors of which, however, are not demonstrably from the town of Bukhara or its vicinity.

8 "Wherever the phonemic structure of the Bukharan Jewish alphabet project differed from the common Tajik one, it reflected features that actually existed in other-though not allTajik dialects too. Nevertheless, Bukharan Jews regarded these features as genuine characteristics of their dialect..." (Rzehak 2008:46).

9 There are also a number of people intent on identifying 'the Jewish dialect of Tajik' (see the following section) as a distinct language variety, most conspicuously among Jews who emigrated from Central Asia. If, as Romaine (2000:23) writes, "the very existence of languages critically depends on the availability of a social group who claims a variety as their own and maintains its distinctiveness from the varieties spoken by its neighbours" and the "[d]istinctiveness can be either wholly or partly imagined," the existence of such people may be enough to establish JвT as a distinct linguistic variety (albeit indirectly, because JBT would comprise only part of 'the Jewish dialect of Tajik'; see the following section). Whether the Tajik language as it is spoken by Jews in Central Asia in general qualifies as a distinct variety is a matter of debate. For example, Borjian (2015:264) remarks that "should their [i.e. Bukharan Jews'] language be deprived of its Hebrew script, its distinction from the Tajik language would be lost as well." Rzehak (2008:49) also states that "Bukharan Jews cannot be distinguished from other speakers of Persian or Tajik in Central Asia by phonetic or morphosyntactical criteria..." These statements indicate that Central Asian Jewish speech does not meet the usual criteria for a language/dialect in the ordinary sense. Indeed, in as early as 1929, the language of the Jews of Bukhara (بؤخارا يهوديلهرى bukhara yähudiläri 'Jews of Bukhara / Bukharan Jews') was described as being identical to that of Tajiks (Käntir 1929:34), which arguably bespeaks the lack of conspicuous linguistic discrepancies between Tajik and Central Asian Jewish Tajik. 
Northern Tajik dialects constitute one of the four major dialect groups into which Tajik dialects are typically classified. ${ }^{10}$ Northern Tajik dialects are characterized primarily by their vowel phonology, on which standard Tajik vowel phonology is essentially based. ${ }^{11}$ They comprise not only JBT and Bukharan Tajik, but also the dialects of such major cities as Samarkand and Xujand.

\section{'Bukharan Jews,' 'Jews in Bukhara,' and 'the Jewish Dialect of Tajik'}

Before we proceed to a discussion on the vowel system of JBT, an explanation of the potentially confusing term 'Bukharan Jews' is in order. The Jewish residents of the town of Bukhara, with whose language we are concerned in this article, constitute not all, but only a subgroup of 'Bukharan Jews.' Despite the presence of the adjective 'Bukharan' in the term, 'Bukharan Jews' is "the common appellation for the Jews of Central Asia whose native language is the Jewish dialect of Tajik" (Zand 1990). ${ }^{12}$ On the other hand, the Jewish inhabitants of the town of Bukhara, with whose language this article is concerned, are very few in number. The companion book to a documentary film about the Silk Road numbers Jews in Bukhara at 'about one hundred and fifty in 2006' (Yabe 2007:186). ${ }^{13}$ As for their present state, an inference can be made, based on remarks made by one of my consultants, that Jewish households in the town of Bukhara numbered a few dozen at the time of my fieldwork (i.e., the summer of 2012).

The term 'the Jewish dialect of Tajik' 14 in the encyclopedia entry cited above also calls for an explanation, because, perhaps contrary to what the term may lead one to think, the referent of 'the Jewish dialect of Tajik' is not always clear or monolithic. In some contexts, the term may refer to zaвoni jahudihoi mahali

10 The other groups of Tajik dialects are Central, Southern, and Southeastern. The reader is referred to Ešniëzov 1977, particularly pp. 62-64, for different classifications of Tajik dialects.

11 Indeed, Bukharan Tajik served as a primary basis for standard Tajik phonological norms.

12 A Jew from Samarkand, for instance, can be identified (and/or identify himself) as a Bukharan Jew. Disagreement seems to exist among Bukharan Jews as to the appropriateness of the term as their self-designation. See Cooper 2012:127-129, 242-243.

13 Yabe (2007) cites no source for this information.

14 The term 'the Jewish dialect of Tajik' is often used interchangeably with such terms as Judeo-Tadzhik, Judeo-Tajik, Bukhori, Bukhari, Bukharic, Bukharan, Bukharian, and Bukharit (Cooper 2012:284) in the literature. 
'(the) language of local Jews' (hereafter ZJM), ${ }^{15}$ a semi-standardized language in which textbooks and newspapers were published in the 1910s, 1920s, and 1930s, inspired by the notion of a single standardized language for Bukharan Jews in Uzbekistan and Tajikistan. In some other contexts the term may be used in reference to the entirety of the different varieties spoken by Jewish residents in various Central Asian towns such as Samarkand, Bukhara, Kokand, Tashkent, and Dushanbe. ${ }^{16}$ Used in this sense, what the term refers to is not a monolithic entity, but a set of varieties. ${ }^{17}$ In yet other contexts, it may refer not only to the varieties spoken by Jews in Central Asia, but also to those that are spoken by Jews of Central Asian origin (i.e., Bukharan Jewish émigrés). Thus, the term 'the Jewish dialect of Tajik' can refer to different language varieties or certain combinations thereof.

Incidentally, the semi-standardized language mentioned above, namely ZJM, is said to have been based on 'the dialects of Bukhara and Samarkand' (Rzehak 2008:49-50). One may therefore be tempted to consider the Jewish varieties of Tajik in the Bukhara-Samarkand area to be largely uniform, and regard remarks made on, say, that in Samarkand to be applicable also to JBT. After all, the Tajik varieties spoken in Bukhara and Samarkand are often jointly referred to as ševahoi tojikoni Samarqandu Buxoro "the dialects of the Tajiks of Samarkand and Bukhara" (Ešniëzov 1977:65) or as "the northern dialects of Samarkand and Bukhara" (Comrie 1981:164) in the literature. Taking the Tajik variety of Samarkand Jews as identical with Jвт may therefore seem unproblematic. This, however, is an oversimplification. While the Tajik dialect of Samarkand is indeed closely related to and mostly mutually intelligible with Bukharan Tajik, as any Tajik-speaking residents of Bukhara and Samarkand would testify, lexical and morphological differences exist between Bukharan Tajik and Samarkandi Tajik. A review of Tajik dialectology (e.g., Ešniëzov 1977; Rastorgueva 1964) also reveals a number of features that separate the two varieties. It is therefore unrealistic to assume that Jewish residents of Bukhara

15 Such terms as zaвoni jahudihoi mahali (виxori) '(the) language of (Bukharan) local Jews' and zuvoni jahudihoji вuxori '(the) language of Bukharan Jews' were also used in reference to ZJM, which was rendered into Uzbek as مä mähäli yähudi tili 'local Jewish/Jew language' (Käntir 1929:35). In a textbook (Badalov et al. 1926), it is referred to simply as לאפזי מאָדרי 'mother tongue.'

16 The varieties that the term 'the Jewish dialect of Tajik' refers to may sometimes include even those spoken by Bukharan Jews from Afghanistan.

17 Cooper (2012:243-246) describes occasions where the differences between the varieties used by Bukharan Jews cause communication difficulties. No authoritative standardization exists among the varieties spoken by Bukharan Jews at present. 
and Samarkand have always shared a single dialect, but that their non-Jewish counterparts have not.

In fact, not only was ZJM different from JBT, it apparently underwent a process of 'Samarkandization' starting in the late $1920{ }^{18}$ ZJM spelling conventions evinced features of the Tajik of Samarkand Jews, particularly from the late 1920 onwards, resulting in ZJM taking on more 'Samarkand-Jewish' (and hence less Jвт) characteristics in the 1920 s and 1930s. There is one easily noticeable feature of zJM that testifies to the increased 'Samarkandiness' of zJM in this period, which coincided with the introduction of a Latin-based writing system. Among the features newly introduced into ZJM then was a spelling convention involving the post-vocalic /b/. The post-vocalic /b/ previously writ-

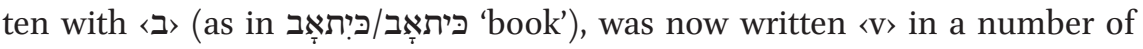
words such as kitov 'book' (Rzehak 2008:48). This use of 〈V〉 probably reflected the fricativization of the post-vocalic /b/, which is a feature of Samarkandi Tajik and the Tajik of Samarkand Jews (see Zarubin 1928; Rastorgueva 1964:47). On the other hand, JBT, in which the post-vocalic /b/ in such words as /kitob/ 'book' and /kabud/ 'blue' is the voiced bilabial plosive today as it probably was a century ago, lacks the fricativization of the post-vocalic $/ \mathrm{b} /$, and in this respect contrasts with the Tajik of Samarkand Jews. For example, in the JBT of Hakham (1902/3), the word for 'book' appears as כיתאב (Hakham 1902/3: unpaginated preface), and not as כיתאוו. The word for 'sleep, dream' appears as כָאב (H.̣akham 1902/3, e.g., on the 8th facing pages), and not as כָזאוו. In contrast, in the vocabulary of the early 2oth century Tajik of Samarkand Jews (Birnbaum 2011b:460), one finds such words as xov 'sleep, dream,' the last letter of which arguably represents a fricative consonant and which contrasts with JBT / $\chi \mathrm{ob} /$ 'sleep.' Also, јвт /kabud/ 'blue' contrasts with kavud 'blue' that appears in a book published in 1934 in ZJM (reproduced in Gulkarov 1998:15). Thus, the use of $\langle\mathrm{V}\rangle$ in the place of the post-vocalic JвT /b/ in a number of words written in

18 This may have been due to an increase in the number of Jewish residents in the Samarkand province, which grew from 2,000 to 12,380 between 1873 and 1914 (Levin 2015:11). By 1926 Samarkand had become "the area with the largest concentration of Bukharan Jews" in the USsR (Zand 1991:404, 1992) and "[w]hile claiming that the written language should be close to the spoken language of the Bukharan Jews, most intellectuals only had in mind the vernacular of Samarkand that they knew best" (Rzehak 2008:47-48). (See also Rzehak 2008:49-50, according to which the issue of which dialect should constitute the basis of ZJM was never on the agenda in the process of its standardization.) In contrast, in 1902 a traveller (Inoue 1903:163) observed that Jews in Turkestan lived mainly in the town of Bukhara, which "apparently became a center of Jewish life in Central Asia in the 16th century” (Zand 2007:258). 
ZJM serves as an example of non-JBT Samarkandi features found in ZJM. This, in turn, is an indication that not every feature of ZJM is shared by JBT.

Accordingly, it seems reasonable to assume that the remarks made about the Tajik of Samarkand Jews do not necessarily apply to JBT. In conclusion, variation among different varieties spoken by the Jewish inhabitants of Central Asia implies that whatever is said or written about 'the Jewish dialect of Tajik' or about ZJM is not necessary applicable to JBT and vice versa. ${ }^{19}$

\section{The Vowel System of JBT}

Rastorgueva (1964:31-41) shows that the vowel systems of Tajik dialects exhibit wide variety in the number of their phonemes (ranging from five to nine) and in their inventories (only /e/ and /o/ are shown to be shared by all of them) ${ }^{20}$ Tajik dialects also vary in the ways they contrast or do not contrast vowel length (see, e.g., Ido 2014:98). The vowel system of JBT, which will be described in the immediately following section, is of a type commonly found among Northern Tajik dialects, which constitute a dialect group vis-à-vis Southern, Central, and Southeastern groups of dialects.

19 For example, in his dictionary of 'Bukharian,' Gulkarov (1998:19) devises a letter (〈 $\mathrm{x} 〉$ with two descenders) which can be construed to represent the sound [ $\hbar]$. However, this does not necessarily point to the presence or absence of $/ \hbar /$ in JBT. He may have included it in the dictionary simply because one of the 'Bukharian' alphabets proposed in the early 2oth century contained a letter for $/ \mathrm{h} /$, namely 〈h〉, or because Samarkand Jews had it as a phoneme (Samarkand Jewish Tajik, but not JBT, has been reported to have $/ \mathrm{h} /$; see Ešniëzov 1977:65). More recent attempts by Central Asian Jewish émigrés to devise a written language are not necessarily representative of JвT either. In particular, Tolmas' (2010) 'Judeo-Tajik' contains expressions that are distinctly un-Jвт. Other attempts include that of Gulkarov (1998), who devises a new set of Cyrillic letters for what he calls zaboni yahudiëni buxorī '(the) language of Bukharan Jews' (his alphabet appears to be based mostly on the Tajik Cyrillic alphabet), and Rybakov (2011), who devises a set of Latin letters for 'Bukharian' (the alphabet is different from the Latinized alphabet that was in use in Central Asia in the 1930s).

20 Buzurgzoda (1940:30-31) describes the various vowels used in Tajik dialects with as many as eighteen symbols, some of which he uses in combination with diacritics. 


\section{The Vowel System of Present-day JBT}

The vowel inventory of present-day JвT consists of six phonemes, namely /i e a $\theta$ o u/. ${ }^{21}$ Figs. 1-4 show the mean formant frequencies of these vowels which four Jewish residents of the old town of Bukhara produced in the test words of / sax/ 'hard,' /se/ 'three,' /si/ 'thirty,' /soxt/ 's/he made,' /sext/ 's/he burnt,' and /suq/ 'evil eye.'22 The bullet in each scatterplot represents the centroid of the consultant's vowel space. The consultants (two males and two females), whose years of birth range from 196o to 1990, are all native Јвт speakers who routinely code-switch to Russian. They also possess competence in Uzbek, but they were evidently much more comfortable communicating in JвT than in Uzbek.

What is immediately evident even from a quick glance at Figs. $1-4$ is that the Jвт vowel system is virtually identical with that of Bukharan Tajik (see scatterplots in Ido 2014:94). In other words, Jв vowel system. This finding is in agreement with the perception of Bukharans that Jвт does not differ from Bukharan Tajik (see the first section).

Not only are the vowel systems of J вт and Bukharan Tajik virtually identical, but so are the generational and gender differences within each variety. A comparison of Figs. 1 and 3 with Figs. 2 and 4 reveals a generational difference in the position of $/ \Theta /$. The younger consultants produce a more fronted $/ \Theta /$ than their older counterparts, suggesting an ongoing fronting of $/ \Theta /$ in Jв T. On the other hand, a comparison of Figs. 1 and 2 with Figs. 3 and 4 shows that the fronting is more prominent in the female consultants' pronunciation than in the male consultants' pronunciation. ${ }^{23}$ These differences are shared by Bukharan Tajik,

21 I do not discuss diphthongs here because there does not seem to be good reason at the phonological level to argue for the existence of diphthongs in Jвт (or in standard Tajik for that matter), though diphthongs are reported to exist in other dialects (see, e.g., Buzurgzoda 1940:35, 40, 41). Huseynov \& Šukurova (1983:44) write that diphthongs are not inherent in Tajik, but occur phonetically.

22 Among these words, /se/ and /si/ were randomized along with thirteen other monosyl-

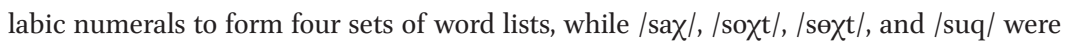
similarly randomized with twenty-three other Bukharan Tajik words to form another four sets of word lists. Consequently, a total of four repetitions were recorded for each of the test words. Formant frequencies were measured with Praat (Boersma \& Weenink 2014). The calculation of mean formant values was made on the NORM website (Thomas \& Kendall 2007). The recordings took place in the household of a Jewish family and in a school for Jewish children, both of which were in the old town of Bukhara, as of the time of fieldwork (August 2013). I would like to thank the consultants, and particularly the one I interviewed in the school for Jewish children, for participating in this investigation.

23 Formant frequency data obtained from four consultants are admittedly insufficient to discern variations in the Јвт vowel system, even considering the fact that the four individuals 


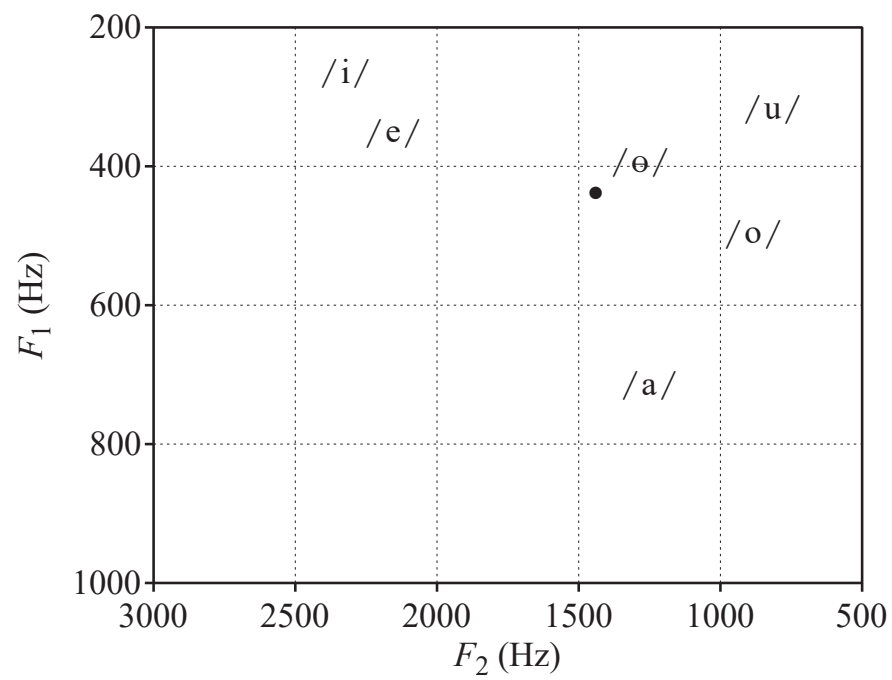

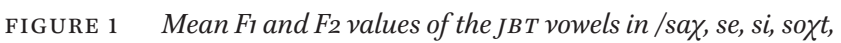
se $\chi$ t, suq/produced by a male informant in his early twenties

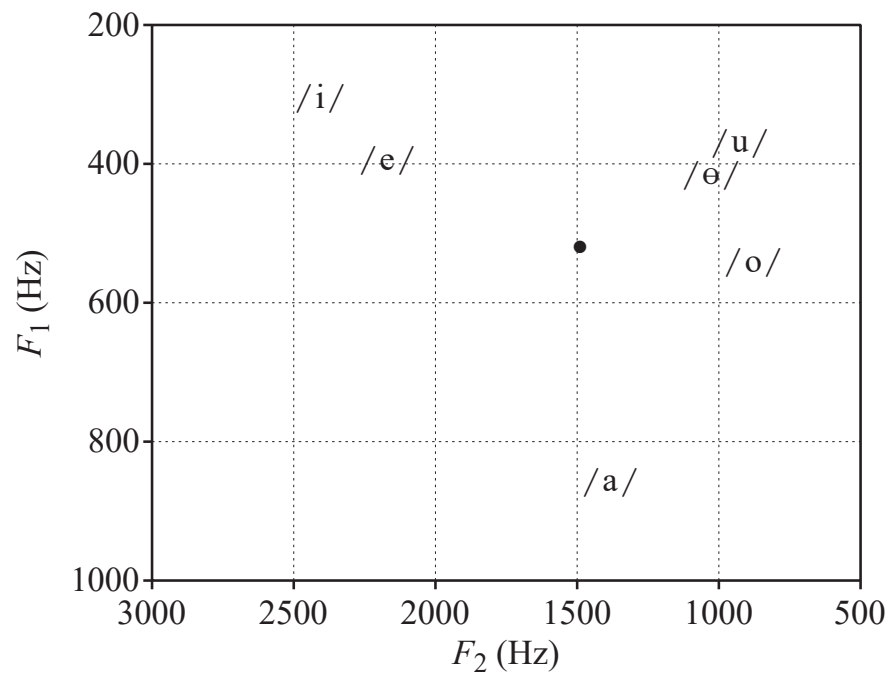

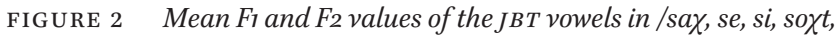
sext, suq/produced by a male informant in his early fifties 


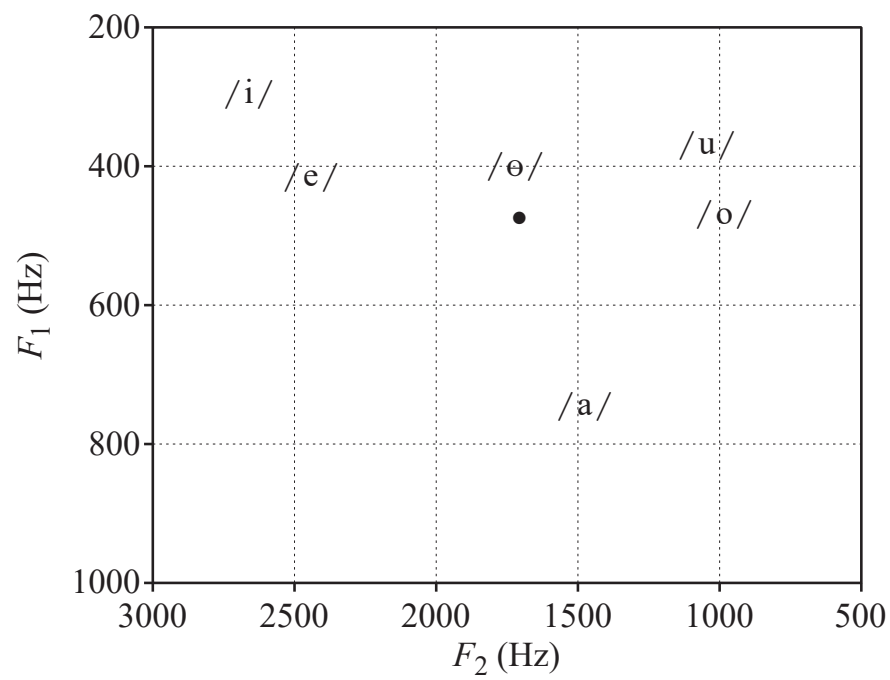

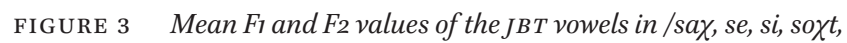
se $\chi$ t, suq/produced by a female informant in her early forties

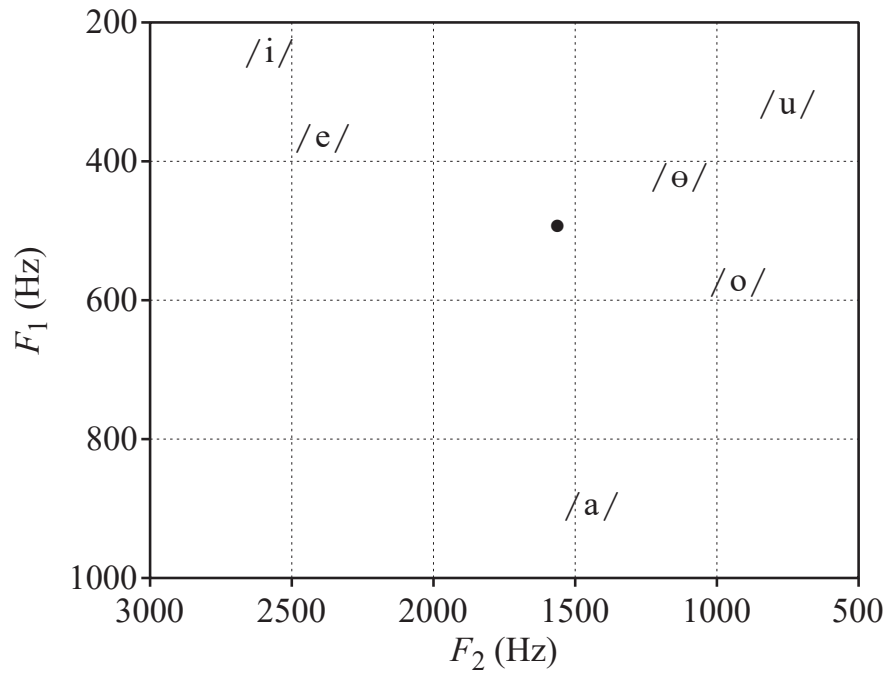

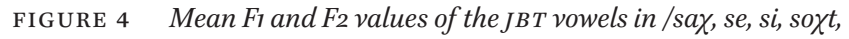
se $\chi$ t, suq/ produced by a female informant in her late forties 
in which there is a general tendency for the position of $/ \mathrm{\theta} /$ to be more front in the speech of younger females. ${ }^{24}$

The observed fronting of $/ \theta /$ and the fact that $/ \theta /$ is almost fully back in the pronunciation of the oldest of the consultants (Fig. 2) allow for the assumption that JBT $/ \Theta /$ (and for that matter Bukharan Tajik / $/$ /, too) was a fully back vowel until a few generations ago. JBT data from the early 20 th century, which are needed to test the assumption, are hard to come by, not least because zJM cannot be equated with JBT (see the second section). However, fortunately, such data do exist in the form of monographs written by a Jew from Bukhara, to which we turn in the immediately following section.

\section{The Vowel System of JвT at the Turn of the 2oth Century}

Simon Hakham (1843-1910), a Bukharan who migrated to Jerusalem in 1890 (Paper 1986:xi) devised a well-developed Jвт orthography which he used in his writings such as Shahin Torah, Sefer Tokhen Alilot, and Musā-nāma. Hakham lived before any attempts at standardizing 'the Jewish dialect of Tajik' took place; we can therefore safely assume that he devised his orthography with the purpose of adequately representing the phonology of his own language, namely Jвт, and hence also that Jв in his orthography. 25

make up at least two to three percent of Jews in Bukhara. However, given the congruity between the JвT and Bukharan Tajik vowel systems, judging the variations observed in the јвт data as an error seems less justifiable than identifying them as related to the corresponding variations observed in the Bukharan Tajik data.

24 This observation is based on formant frequency data obtained by this author from eleven native Bukharan Tajik speakers whose years of birth range from 1944 to 1997. A paper in which this pool of data is analysed is currently in preparation, but a cursory analysis of the formant frequency data seems to suggest that the tendency is more prominent among Bukharan Tajik speakers who were born between the 1960s and 1980s than it is among those who were born before or after that period, though admittedly this analysis needs further scrutiny and/or refinement.

25 It is worth noting that, while Ḥakham's orthography differs radically from the orthography of Dāniyal-nāma (described in Netzer 1972), it bears much similarity to the orthography employed in Khudāidād (reproduced in Salemann 1897). Since the copies of Dāniyalnāma and Khudāidād, both of which were presumably written by Bukharan Jews, appear to predate Ḧakham's own works (see Saleman 1897:iii-iv; Margoliouth 1909:269; Netzer 1971:147; Yastrebova \& Azad 2015:677,682), it is possible that Hakham was (selectively) influenced by the orthography used in the latter. It is also possible that Hakham himself was involved in formulating the orthography employed in Khudāidād, in which case the orthography may be a prototype of Ḥakham's J в T orthography later used in his own writings. In any case, Hakham's orthography departs from that employed in Khudāidād in 
TABLE 1 Correspondence between present-dayJBT vowel phonemes and JBT vowel letters/ signs that appear in Hakham (1902/3)

\begin{tabular}{|c|c|c|c|}
\hline \multirow{2}{*}{$\begin{array}{l}\text { Present-day JBT vowel } \\
\text { phonemes }\end{array}$} & \multicolumn{3}{|c|}{ Jвт vowel letters/signs in the beginning of the 20 th } \\
\hline & Final & Medial & Initi \\
\hline /i/ & ? & ஒ & אִי \\
\hline /e/ & ? & י & אֵי \\
\hline $\mid \mathrm{a} /$ & ח & ? & $\underline{~}$ \\
\hline $10 /$ & « & ॠ & 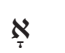 \\
\hline$|\theta|$ & $i$ & $i$ & 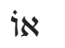 \\
\hline$/ \mathrm{u} /$ & i & i & אוּ \\
\hline
\end{tabular}

Table 1 shows how the vowel letters/signs in his orthography correspond with the six vowel phonemes of present-day JBт. ${ }^{26}$

There are a couple of peculiarities in the correspondences shown in Table 1. First, Hakham's orthography assigns $\langle\boldsymbol{i}\rangle /\langle i\rangle$ to his vowel that corresponds to

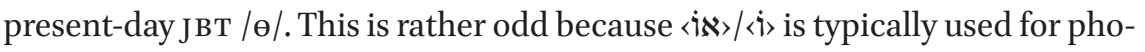
nemes whose phonetic values approximate (or are thought to have approximated) [o] in texts with Tiberian vocalization - for instance, in the accepted (Sephardi) pronunciation of Hebrew, to which Hakham must have been exposed after he migrated to Jerusalem, $\langle$ אוֹ $\rangle\langle\rangle$ represented /o/, whose value

a number of important ways. Hakham's orthography, but not the orthography used in

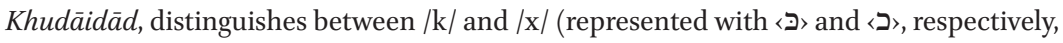
in Hakham's orthography) and between the voiceless and voiced affricates in the alveolar-

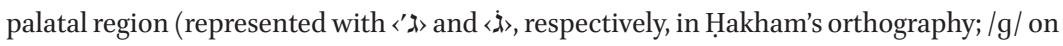
the other hand is represented with $\langle\dot{\langle}\rangle)$. H. Hakham is also remarkably consistent in applying his spelling conventions to his own writings. For example, the present stem of the verb for 'to become,' which is almost always spelled שֵ in Hakham's orthography, is spelled vari-

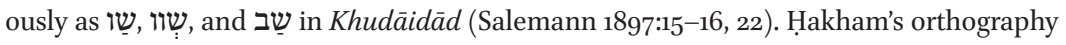
departs from the orthography of Khudāidād in a number of other ways as well, e.g., 〈’। and 〈’ for /e/ in Khudāidād and Ḥakham's major writings, respectively.

26 Table 1 is compiled from the second volume of a three-volume publication titled Shahin Torah. The volume comprises part of Shahin Torah into which another of Hakham's works Sefer Tokhen Alilot is interleaved (see Paper 1986:xxiii-xxiv). Judging from yet another of Hakham's works, namely Musā-nāma (Paper 1986), Hakham used basically the same orthography for a number of his works (see also Sundermann 1966:277-278). 
likely approximated [o] (see Morag 2007:557). ${ }^{27}$ This implies that present-day J В $/ \Theta /$ was more back and had a sound value qualitatively approximating [o] at the beginning of the 20 th century. ${ }^{28}$ This is in conformity with the assumption stated in the preceding section, namely that Jв $/ \Theta /$ was a fully back vowel until a few generations ago.

Thus, one peculiarity of Table 1 can be ascribed to the fronting of /o/ (present-day $/ \Theta /$ ). There however remains another peculiarity of Table 1 , namely Hakham's assignment of $\langle\boldsymbol{N}$; $\rangle /\langle\underset{\text { Tे }}{\rangle}$ to his vowel corresponding to present-day JBT /o/. It does not seem far-fetched to assume that, if the Јвт vowel that Hakham

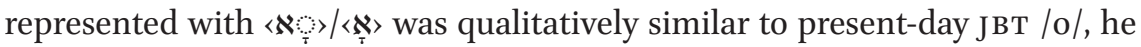

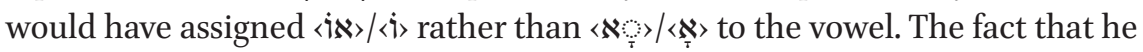
did not assign $\left\langle i{ }^{\prime}\right\rangle /\langle i\rangle$ to the vowel, then, suggests that his vowel corresponding to present-day Јвт /o/ qualitatively differed from present-day Јвт $/ 0 / .^{29}$ What

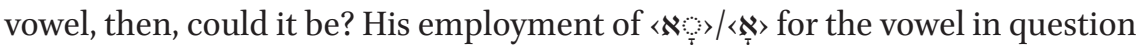
implies that the vowel it represented had a value that qualitatively approxi-

27 Studies such as Morag (1959:250) and Parfitt (1984:261) suggest that the accepted pronunciation of Modern Hebrew in the late 19th century was the Sephardi pronunciation, "on which Modern Spoken Hebrew [... ] is fundamentally based." Morag (1993:213) states more specifically that the late 19th-century Modern Hebrew phonological system comprised Sephardi vowels and stress patterns blended with Ashkenazi consonants. Incidentally, the F1 and F2 values of Modern Israeli Hebrew /o/ for adult male speakers are 478 and 944, respectively (Most et al. 2000). See also Aronson et al. (1995:287) for the mean F1 and $\mathrm{F} 2$ values of $/ \mathrm{o} /$ produced by six male Israeli Hebrew speakers (the reader is referred to Kreitman 2013:83-85 for a concise review of previous scholarship on Modern Hebrew vowels). These formant values are in general agreement with those of present-day Jв $\mathrm{T} / \mathrm{o} /$, whose mean F1 and F2 values in the male consultants' J BT are 518 and 880, but not with those of present-day Јвт / $\Theta /$, whose mean $\mathrm{F}_{1}$ and $\mathrm{F}_{2}$ values in the male consultants' Jвт are 403 and 1153. For reference, the mean F1 and F2 values of present-day Jвт vowels are as follows: /i/ (284, 2363.6), /e/ (371.8, 2161), /a/ (784.6, 1315.5), /o/ (517.5, 880.1), /e/ (402.9, $1153.2), / \mathrm{u} /(342.5,868.7)$ for the male consultants and /i/ $(253.2,2449.5), / \mathrm{e} /(357.4,2271)$, /a/ (803.9, 1344.6), /o/ (533.4, 902.8), /ө/ (406.9, 1205.9), /u/ $(316.5,784.7)$ for the female consultants.

28 This is provided that Hakham did not accord his JBT orthography with the Yemenite pronunciation, in which, according to Morag (2007:559), holem is realized as $\ddot{o}$, a sound which he describes to be similar to eu in French реur/рœв/. See also Shachmon 2013:403, wherein it is noted regarding the Hebrew reading traditions of Yemenite Jews that "Hebrew holem is a central rounded vowel, roughly an open ō, in Șan'ā and the north."

It allows the speculation that the vowel had no close equivalent in Modern Israeli Hebrew, which has only /i, e, a, o, u/ (Laufer 1999:97). 
דִי

e u אוs

\section{o אi}

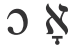

$\mathrm{a} \underline{\mathrm{N}}$
FIGURE 5

Reconstructed late 19th-to early 2oth-century JB T vowel system based on Hakham's orthography

mates [0], ${ }^{30}$ which ? is thought to have originally represented (Johnson \& Goerwitz 1995; Goerwitz 1996:491; Khan 1997:91; 2013b:773; Rendsburg 1997:78). ${ }^{31}$ Interestingly, Morag (2007:559) and Khan (2013a:346) note, respectively, that "[s]ome Persian-speaking communities realize the qameș as a rounded lowermid back vowel, [å]" and that in "Biblical reading traditions of communities who speak Iranian languages [...] long qameș is pronounced with a back qual-

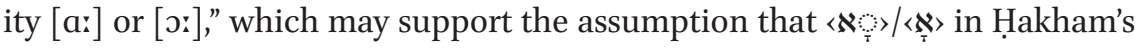
orthography represents a vowel phoneme whose value approximated [o]. Accordingly, JBT in the beginning of the 2oth century can be tentatively estimated to have had the six vowels presented in Fig. 5 .

As is clear from Table 1 and Figs. $1-5$, Hakham's Jв в vowel system (Fig. 5) differs from the present-day J BT vowel system, with Hakham's /o/ and / $/ 0$ corresponding to present-day J В $/ \Theta /$ and $/ \mathrm{o} /$, respectively. This difference probably indicates a vowel chain shift, which will be discussed in the immediately following section.

\section{Vowel Chain Shift}

The vowel system shown in Fig. 5 and that of the oldest of our consultants (Fig. 2) share the fully or very back realization of the vowel phoneme that is /o/ in Fig. 5 and /e/ in Fig. ${ }^{32}{ }^{32}$ This suggests that the generational difference in the

30 To be more precise, 〈〉 is thought to have originally represented Tiberian Hebrew / $/$, whose value is estimated to be (qualitatively) [0].

31 〈న⿱ 〉 is used for [0] also in the YIVo orthography (Aronson 1996; Kleine 2003:263-264). Why

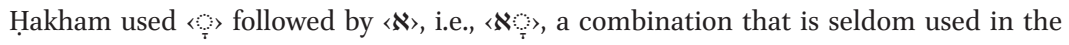
orthographies of historical and contemporary Jewish languages (see, however, Gesenius 1910:45; Fernández 1997:12; Muraoka 2011:28-29; and Reymond 2013:\$3.3) for representing the vowel is beyond the scope of this article, but certainly merits a separate analysis, as does his use of 〈ה〉 and 〈े, respectively, as the word-final and word-medial forms for /a/, which possibly reflects the spelling convention of Persian (see Forbes 1869:7-8) and/ or that of Hebrew.

32 It actually more closely resembles the vowel system of present-day Tashkent Uzbek (see Ido 2014:96) and also shows some resemblance to the Timurid Persian vowel system, in 
Late 19th- to early 2oth-century JBT

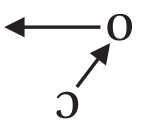

a

FIGURE 6 JBT chain shift
Present-day JBT

$\theta \quad 0$

a

\section{Early New Persian Present-day Tajik}

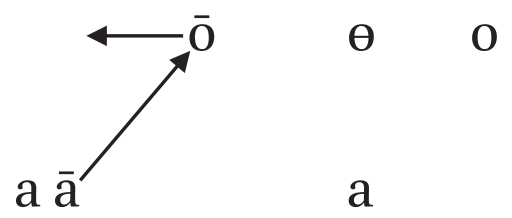

FIGURE 7 Northern Tajik chain shift

position of $/ \theta /$ in present-day JBT represents a shift of JBT /o/ in the late 19th and early 2oth century to the position of present-day Jвт $/ \Theta /$. It is also clear from the comparison of Figs. 1-4 with Fig. 5 that the fronting accompanied a shift (i.e., raising) of Jв $/ \mathrm{J} /$ of the late 19th and early 20 th century to the position of present-day Јвт $/ 0 /$, and hence that the fronting and raising constitute a chain shift which can be represented schematically as in Fig. 6.

Incidentally, this chain shift can be identified as constituting part of the Northern Tajik chain shift (Ido 2009) that took place in Northern Tajik dialects in general (Fig. 7). This is hardly surprising in itself, as Jв те belongs to Northern Tajik dialects (see the first section).

The identification of the Jвт chain shift as an intermediate stage in the Northern Tajik chain shift has an interesting consequence-it enables us to combine Fig. 6 with Fig. 7, thereby effectively reconstructing the process by which the Northern Tajik chain shift unfolded. This is of particular impor-

which the vowels corresponding to present-day Tajik /u/, / $/$ /, and /o/ can all be estimated to be fully back vowels (Ido 2015:128). Interestingly, it also resembles the vowel system which Buzurgzoda (1940:42) refers to as that of the adaвi 'literary' (i.e., standard) language. The vowels corresponding to present-day јвт $/ \Theta /$ and $/ 0 /$ are presented, respectively, as $\mho / 0$ and $\supset$ in Buzurgzoda (1940:40-41), according to which $\mho / o$ and $\supset$ are present in the dialect group to which the dialects of Xujand, Samarkand, etc., belong. 


\section{Early New Persian}

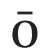

a $\bar{a}^{\nearrow}$
Late 19th- to early 2oth-century Tajik

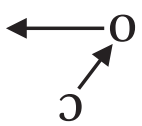

a
Present-day Tajik

$\theta \quad 0$

a

FIGURE 8 Northern Tajik chain shift (revised)

tance for the study of the vowel systems employed in different varieties of New Persian, such as Iranian Persian and Afghan Dari, because the Northern Tajik chain shift (and the fronting of the close-mid rounded back vowel in particular) is a very distinctive, if not unique, ${ }^{33}$ feature of Tajik (see Windfuhr 2009:457458; Windfuhr \& Perry 2009:425; Miller 2012:165-167). Combining Fig. 6 with Fig. 7 yields Fig. 8. Following Windfuhr (2009:447), Early New Persian is dated to the 1oth and 11 th centuries in this article. ${ }^{34}$

The reconstructed Northern Tajik chain shift shown in Fig. 8 indicates that, in Bukhara at any rate, the raising of Early New Persian $\bar{a}$ preceded the fronting of Early New Persian $\bar{o}$, and hence that the Northern Tajik chain shift was likely a push-chain shift. ${ }^{35}$

In summary, an analysis of JBT formant data reveals a fronting of the closemid rounded back vowel in progress in JBT, which constitutes part of the JBT chain shift in which /o/ and /o/ became / $/$ / and /o/, respectively. The JBT chain shift in turn can be identified as constituting part of the Northern Tajik chain shift, which moved Early New Persian $\bar{a}$ and $\bar{o}$ to the positions of /o/ and / $\Theta /$, respectively. This effectively elucidates the process by which the Tajik vowel system was established.

33 Éfimov (1965:10-13) reports a similar shift in the Yakawlang dialect of Hazaragi.

34 The dating of the term 'Early New Persian' is diverse in the literature (Miller 2012:156). For example, Paul (2013a) identifies Early New Persian as spanning "the stages of New Persian from its beginning, the 8th century, to approximately the early 13th century," while Windfuhr \& Perry (2009:533) assigns it to 1100-1300 AD. In Paul (2013b:9), Early New Persian is described as "the form of Persian [...] that originated in northeast Iran during the 9 th/1oth centuries CE."

35 Livshits et al. (1974:282) note that the transition of $\bar{a}$ to $o$ apparently took place in the 16th and 17 th centuries, but Fig. 8 suggests that, at least in Bukhara, the transition was not complete until the late 19th century. 


\section{Conclusions}

In this article, I described the vowel system of present-day JBT and contrasted it with the JBT vowel system of the late 19th and early 2oth centuries which was reconstructed from the JBT orthography devised by Simon Hakham (1843-1910). The description revealed that the vowel system of present-day JBT is identical to that of Bukharan Tajik. It also revealed a generational difference in the position of the vowel phoneme / $\Theta /$, which pointed to the possibility that JBT /e/ may have been a fully back vowel until a few generations ago. A comparison between the present-day JBT vowel system and that reconstructed for the late 19th to early 20 th century showed that present-day JBT / $/$ / had a value approximating [o] at the turn of the 2oth century, suggesting that JB $\mathrm{B} / \Theta /$ was indeed a fully back vowel about a century ago. In addition, the comparison showed that the JBT vowel system likely underwent a chain shift in which JBT $/ 0 /$ and $/ 0 /$ of the late 19 th and early 20 th century moved to the positions of present-day Jвт $/ \Theta /$ and /o/, respectively. This chain shift was identified as constituting part of the vowel shift that Northern Tajik dialects, of which JBT is one, underwent. This led to the tentative conclusion that, in the Northern Tajik chain shift Early New Persian $\bar{a}$ shifted before $\bar{o}$ did, shedding light on the process whereby the present-day Tajik vowel system was established. This finding has implications for the understanding of the establishment of Tajik as a language (more or less) distinct from other southwestern Iranian languages, because the Northern Tajik chain shift is one of the features that most saliently characterize Tajik as distinct from Iranian Persian and Afghan Dari.

\section{Abbreviations}

JBT: Jews' Bukharan Tajik

ZJM: zaвoni jahudihoi mahali '(the) language of local Jews'

\section{References}

Aronson, Howard I. 1996. "Yiddish." In The World's Writing Systems, eds. Peter T. Daniels \& William Bright. Oxford: Oxford University Press, 735-742.

Aronson, L., J. Rosenhouse, G. Rosenhouse, \& L. Podoshin. 1995. "An Acoustic Analysis of Modern Hebrew Vowels and Voiced Consonants." Journal of Phonetics 24: 283-293. Bacher, Wilhelm. 1898. "Das jüdisch-buchârische Gedicht Chudâidâd." Zeitschrift der Deutschen Morgenländischen Gesellschaft 52: 197-212. 
Bacher, Wilhelm. 1899. "Der Dichter Jûsuf Jehûdi und sein Lob Moses." Zeitschrift der Deutschen Morgenländischen Gesellschaft 53: 389-427.

Badalov, R., B. Grinberg, \& E. Mulloqandov. 1926. Rafiqi kūdakon. Tashkent: Uzbekskoe Gosudarstvennoe Izdatel'stvo (reprinted in Rybakov 2011).

Benor, Sarah Bunin. 2008. "Towards a New Understanding of Jewish Language in the Twenty-First Century." Religion Compass 2.6: 1062-1080.

Birnbaum, Solomon A. 2011a. "Xudaidad." In A Lifetime of Achievement: Six Decades of Scholarly Articles by Solomon A. Birnbaum, vol. 1: Linguistics, ed. Erika Timm. Berlin: Walter de Gruyter, 463-502.

Birnbaum, Solomon A. 2011b. "A Bukharic Vocabulary." In A Lifetime of Achievement: Six Decades of Scholarly Articles by Solomon A. Birnbaum, vol. 1: Linguistics, ed. Erika Timm. Berlin: Walter de Gruyter, 427-462.

Boersma, Paul \& David Weenink. 2014. Praat: Doing Phonetics by Computer (Version 5.3.84), online at http://www.praat.org/, accessed August 26, 2014.

Borjian, Habib. 2015. “Judeo-Iranian Languages." In Handbook of Jewish Languages, eds. Lily Kahn \& Aaron D. Rubin. Leiden: Brill, 234-296.

Buzurgzoda, Lutfullo. 1940. Fonetikaji zaвoni adaвiji toçik. Stalinoвod: Naşrijoti Davlatiji Toçikiston.

Comrie, Berhard. 1981. The Languages of the Soviet Union. Cambridge: Cambridge University Press.

Cooper, Alanna E. 2012. Bukharan Jews and the Dynamics of Global Judaism. Bloomington, IN: Indiana University Press.

Éfimov, Valentin Aleksandrovich. 1965. Yazȳk afganskikh khazara: Yakaulangskiü dialekt. Moscow: Nauka.

Ešniëzov, M. 1977. Dialektologiyai tojik (qismi yakum). Dushanbe: Universiteti Davlatii Tojikiston ba nomi V. I. Lenin.

Fernández, Miguel Pérez. 1997. An Introductory Grammar of Rabbinic Hebrew. Leiden: Brill.

Forbes, Duncan. 1869. A Grammar of the Persian Language, 4th edition. London: Wm. H. Allen \& Co.

Gesenius, Wilhelm. 1910. Gesenius' Hebrew Grammar as Edited and Enlarged by E. Kautzsch, trans. Arthur E. Cowley. Oxford: Clarendon Press.

Goerwitz, Richard L. 1996. "The Jewish Scripts." In The World's Writing Systems, eds. Peter T. Daniels \& William Bright. Oxford: Oxford University Press, 487-498.

Gulkarov, Josef. 1998. Étimologicheskiŭ slovar' bukharsko-evrěskogo yazȳka. Tel-Aviv: Union of Bukharian Jews in Israel.

Hakham, Simon. 1902-1903. Shahin Torah (second volume). Jerusalem: NP.

Huseynov, Xudoydod \& Kimiyo Šukurova. 1983. Lughati terminhoi zabonšinosī.

Dushanbe: Maorif.

Ido, Shinji. 2007. Bukharan Tajik. Munich: Lincom. 
Ido, Shinji. 2009. "Rensa suii to gengo sesshoku no intāfeisu." In Gengo-nō-ninchi no kagaku to gaikokugo shūtoku, ed. Tōhoku Daigaku Gengo Ninchi Sōgō Kagaku CoE Ronbunshū Kankō Iinkai. Tokyo: Hitsuji Shobō, 7-20.

Ido, Shinji. 2012. Tajikugo bunpō binran. Sendai: Tohoku University Press.

Ido, Shinji. 2014. "Bukharan Tajik." Journal of the International Phonetic Association 44.1: 87-102.

Ido, Shinji. 2015. “New Persian Vowels Transcribed in Ming China." In Iranian Languages and Literatures of Central Asia: from the 18th Century to the Present, eds. Matteo De Chiara \& Evelin Grassi. Paris: Association pour l'avancement des études iraniennes, 99-136.

Inoue, Masaji. 1903. Chūō ajia ryokōki. Tokyo: Min’yūsha.

Jankowski, Henryk. 2003. "On the Language Varieties of Karaims in the Crimea." Studia Orientalia 95: 109-130.

Johnson, Robert M. \& Richard Goerwitz. 1995. "A Simple, Practical System for Transliterating Tiberian Hebrew Vowels." Hebrew Studies 36: 13-24.

Käntir, L. M. 1929. Ozbekistanda mähalli yähudilär. Samarkand: Ozbek Däwlät Näshriyati.

Khan, Geoffrey. 1997. "Tiberian Hebrew Phonology." In Phonologies of Asia and Africa, vol. 1, ed. Alan S. Kaye. Winona Lake, IN: Eisenbrauns, 85-102.

Khan, Geoffrey. 2013a. "Biblical Hebrew: Pronunciation Traditions." In Encyclopedia of Hebrew Language and Linguistics, vol. 1, eds. Geoffrey Khan et al. Leiden: Brill, 341-352.

Khan, Geoffrey. 2013b. "Tiberian Hebrew Phonology." In Encyclopedia of Hebrew Language and Linguistics, vol. 3, eds. Geoffrey Khan et al. Leiden: Brill, 769-778.

Kleine, Ane. 2003. "Standard Yiddish." Journal of the International Phonetic Association 33.2: 261-265.

Kreitman, Rina. 2013. "Phonetics of Modern Hebrew: Acoustic." In Encyclopedia of Hebrew Language and Linguistics, vol. 3, eds. Geoffrey Khan et al. Leiden: Brill, 77-86.

Laufer, Asher. 1999. "Hebrew." In Handbook of the International Phonetic Association, ed. International Phonetic Association. Cambridge: Cambridge University Press, 96-99.

Lazard, Gilbert, Walter Joseph Fischel, Herbert H. Paper, \& Shaul Shaked. 2007. "JudeoPersian." In Encyclopaedia Judaica, second edition, vol. 11, ed. Fred Skolnik. Detroit, MI: Thomson Gale, 548-559.

Levin, Zeev. 2015. Collectivization and Social Engineering: Soviet Administration and the Jews of Uzbekistan, 1917-1939. Leiden: Brill.

Livshits V. A., N. Masumi, \& D. Tadzhiev. 1974. “Tadzhikskiǔ yazȳk.” In Tadzhikskaya Sovetskaya Sotsialisticheskaya Respublika, ed. M. S. Asimov. Dushanbe: Tadzhikskaya Sovetskaya Éntsiklopediya, 281-29o. 
Margoliouth, George. 1894. "Persian Hebrew MSS. in the British Museum." The Jewish Quarterly Review 7.1: 119-120.

Margoliouth, George. 1909. Catalogue of the Hebrew and Samaritan Manuscripts in the British Museum. London: British Museum.

Miller, Corey. 2012. "Variation in Persian Vowel Systems." Orientalia Suecana 61:156-169. Morag, Shelomo. 1959. "Planned and Unplanned Development in Modern Hebrew." Lingua 8: $247-263$.

Morag, Shelomo. 1993. "The Emergence of Modern Hebrew: Some Sociolinguistic Perspective." In Hebrew in Ashkenaz. ed. Lewis Glinert. Oxford: Oxford University Press, 208-221.

Morag, Shelomo. 2007. "Pronunciations of Hebrew." In Encyclopaedia Judaica, second edition, vol. 16, ed. Fred Skolnik. Detroit, MI: Thomson Gale, 547-562.

Moreen, Vera Basch. 2000. In Queen Esther's Garden: An Anthology of Judeo-Persian Literature. New Haven, ст: Yale University Press.

Most, Tova, Ofer Amir, \& Yishai Tobin. 2000. "The Hebrew Vowel System: Raw and Normalized Acoustic Data." Language and Speech 43.3: 295-308.

Muraoka, Takamitsu. 2011. A Grammar of Qumran Aramaic. Leuven: Peeters.

Netzer, Amnon. 1971. "Dāniyāl-nāme: A Exposition of Judeo-Persian." In Islam and Its Cultural Divergence: Studies in Honor of Gustave E. von Grunebaum, ed. Girdhari L. Tikku. Urbana, IL: University of Illinois Press, 145-164.

Netzer, Amnon. 1972. "Dāniyāl-nāma and its Linguistic Features." Israel Oriental Studies 2: $305-314$.

Paper, Herbert H., ed. 1986. The Musā-nāma of R. Shim'on Hakham. Cincinnati, он: Hebrew Union College Press.

Paul, Ludwig. 2013a. "Early New Persian." In Encyclopcedia Iranica, online edition, http://www.iranicaonline.org/articles/persian-language-1-early-new-persian, accessed March 28, 2016.

Paul, Ludwig. 2013b. A Grammar of Early Judaeo-Persian. Wiesbaden: Reichert Verlag. Parfitt, Tudor. 1984. "The Contribution of the Old Yishuv to the Revival of Hebrew." Journal of Semitic Studies 29: 255-265.

Rastorgueva, Vera Sergeevna. 1964. Opȳt sravnitel'nogo izucheniya tadzhikskikh govorov. Moscow: Nauka.

Rendsburg, Gary A. 1997. "Ancient Hebrew Phonology." In Phonologies of Asia and Africa, vol. 1, ed. Alan S. Kaye. Winona Lake, IN: Eisenbrauns, 65-83.

Reymond, Eric D. 2013. Qumran Hebrew: An Overview of Orthography, Phonology, and Morphology. Atlanta, GA: Society of Biblical Literature.

Romaine, Suzanne. 2000. Language in Society: An Introduction to Sociolinguistics, second edition. Oxford: Oxford University Press.

Rybakov, Imanuel. 2011. Easy Bukharian. New York: Association of the Bukharian Jewish Youth of the USA Achdut-Unity. 
Rzehak, Lutz. 2008. "The Linguistic Challenge: Bukharan Jews and Soviet Language Policy." In Bukharan Jews in the 2oth century, eds. Ingeborg Baldauf, Moshe Gammer, \& Thomas Loy. Wiesbaden: Reichert Verlag. 37-55.

Salemann, Carl. 1897. Chudâidât: ein jüdisch-buchârisches Gedicht. St. Petersburg: Imperatorskoŭ Akademĭi Nauk."

Shachmon, Ori. 2013. "Hebrew Component in Judeo-Arabic, Yemen." In Encyclopedia of Hebrew Language and Linguistics, vol. 2, ed. Geoffrey Khan. Leiden: Brill, 402-406.

Shapira, Dan. 2010a. "Dāniyal-Nāma." In Encyclopedia of Jews in the Islamic world, vol. 2, ed. Norman A. Stillman. Leiden: Brill, 25.

Shapira, Dan. 201ob. "Khwāja Bukhārā'̀̄." In Encyclopedia of Jews in the Islamic world, vol. 3, ed. Norman A. Stillman. Leiden: Brill, 161.

Shterenshis, Michael. 2002. Tamerlane and the Jews. London: RoutledgeCurzon.

Sundermann, Werner. 1966. "Zum Judenpersisch der Mas'at Binyāmīn." Mitteilungen des Instituts für Orientforschung 11: 275-300.

Thomas, Erik R. \& Tyler Kendall. 2007. NORM: The Vowel Normalization and Plotting Suite. Online at http://ncslaap.lib.ncsu.edu/tools/norm/, accessed August 26, 2014. Tolmas, Chana. 2010. Judeo-Tajik for Hebrew and English speakers. Jerusalem: Center for the Research and Study of the Jewish Communities in Iran, Bukhara and Afghanistan.

Windfuhr, Gernot. 2009. "Persian." In The World's Major Languages, second edition, ed. Bernard Comrie. London: Routledge, $445^{-459 .}$

Windfuhr, Gernot \& John R. Perry. 2009. "Persian and Tajik." In The Iranian Languages, ed. Gernot Windfuhr. London: Routledge, 416-544.

Yabe, Yūichi. 2007. "Oashisu no michi wa kewashi." In Shin shirukurōdo: gekidō no daichi o yuku, jō, ed. NH K Special New Silk Road Project. Tokyo: Japan Broadcasting Publishers Association, 157-197.

Yastrebova, Olga \& Arezou Azad. 2015. "Reflections on an Orientalist: Alexander Kuhn (1840-88), the Man and his Legacy." Iranian Studies 48.5: 675-694.

Zand, Michael. 1990. "Bukhara vii. Bukharan Jews." In Encyclopcedia Iranica, IV/5, ed. Ehsan Yarshater. London: Routledge \& Kegan Paul, 530-545.

Zand, Michael. 1991. "Notes on the Culture of the Non-Ashkenazi Jewish Communities under Soviet Rule." In Jewish Culture and Identity in the Soviet Union, eds. Yaacov Ro'i \& Avi Beker. New York: New York University Press, 348-444.

Zand, Michael. 2007. "Bukhara: The Origin and Sources of the Jewish Community." In EncyclopaediaJudaica, second edition, vol. 4. ed. Fred Skolnik. Detroit, MI: Thomson Gale, 258-259.

Zarubin, Ivan Ivanovich. 1928. "Ocherk razgovornogo yazȳka Samarkandskikh Evreev." Iran 2: $95^{-180 .}$ 


\section{Shinji Ido}

received his $\mathrm{PhD}$ from the University of Sydney in 2002. He is currently an Associate Professor of Linguistics at Nagoya University in Japan. His previous publications include Agglutinative Information: A Study of Turkish Incomplete Sentences (2003) and Tacikçe Dilbilgisi (2006). 